\title{
WHAT SKILLS ARE INVOLVED IN OPEN VIRTUAL MOBILITY? A STUDENTS' PERSPECTIVE FROM ITALY AND SPAIN
}

Gemma Tur Ferrer, Universitat de les Illes Balears, Spain, Antonella Poce, Università di Modena e Reggio Emilia, Maria Rosaria Re, Università di Roma Tre, Italy, Sofia Villatoro, Universitat de les Illes Balears, Spain

\section{Abstract}

Virtual Mobility can enhance curriculum development in Higher Education by promoting international co-design and collaborative work among students and lecturers through the use of Information and Communication Technologies (ICT). During the spread of COVID-19 pandemic, virtual forms of students' mobility increased considerably, allowing learners to continue or start VM experience even if boarders and campuses around the world were closed. The recent outbreak in interest and activity related to $\mathrm{VM}$ requires educational researchers to study this learning practice in depth in order to provide data and effective indications in terms of skills promotion. During the academic year 2020-2021, a team of lecturers of Teacher Education programs from the Roma Tre University (Rome, Italy) and the University of the Balearic Islands (Balearic Islands, Spain) agreed to work in open digital environment, organising specific VM activities for 38 university students. Specifically, students were asked to meet online, design and collaboratively create, in groups from the two countries, Open Digital Resources (OERs) to be used in international online contexts with their future pupils. This paper presents the design of the learning experience together with self-assessment results of the professional and transverse competences promoted. Conclusions also reflect on the new improvements to be done for new editions of the activity.

\section{Introduction}

The biggest challenges faced by universities and made more urgent by the spread of the pandemic are clearly globalisation and digital transformation (Buchem et al., 2018; Kaplan, 2020). Virtual Mobility (VM), defined as "a set of ICT supported activities, organized at institutional level, which realize or facilitate international, collaborative experiences in a context of teaching and/or learning" (Op de Beeck, \& van Petegem, 2013), should be a valuable support to both challenges, thanks to the possibility, within this kind of activities, of knowledge promotion exchange, intercultural understanding enhancement 
and digital skills development (Poce et al., 2020a). Moreover, as stated by Ruiz Corbella and Garcia Aretio (2010), VM should be considered a democratic form of learning: thanks to cross-border collaboration with people from different backgrounds and cultures through ICT, university students can have access to a wider institutional market as well as brings greater interactivity and flexibility for the affordances of the technological tools in which it is based. Movement restrictions during the COVID-19 pandemic led many institutions to organise VM experiences instead of physical mobility: according to International Association of Universities data (2020), the virtual mobility provision during the pandemic increased for over $60 \%$ of HEIs around the world. In this way, the VM intrinsic characteristics and strengths have been adapted to a more flexible inter-university learning experience, whose design is in line with the learning content of the specific courses in which students are enrolled.

\section{The Virtual Mobility learning design}

The learning activity was designed following Rajagopal et al. (2020b) guide for Open Virtual Mobility activities, and in table one there are the main areas and all the elements that were contemplated by the team of teachers.

Table 1: Learning design following the OpenVM guide (Rajagopal et al., 2020b)

\begin{tabular}{ll}
\hline Virtual mobility & Plements \\
Context & involved in the implementation of the VM activity. \\
& Partner institutions. Two institutions are involved, one from Italy (RomaTre \\
& University) and one from Spain (University of the Balearic Islands) \\
& Level of education and Educational programme. Students from the UIB were \\
doing a subject in year 3, "Technological Means and Resources in the \\
Teaching-Learning Process in Primary Education". In Italy there were students \\
doing the "Educational Research Methodology" (subject in year 1) and \\
"Museum, Experiment and Reading" (subject in year 4). Students from the \\
"Educational Research Methodology" course were at the first year of their \\
Teacher Education program whilst students from the "Museum, Experiment \\
and Reading" course were at their fourth year \\
Intended learning outcomes. The activity was mainly designed to promote \\
virtual mobility among student teachers. And as learning aims, the following \\
were the main ones: understanding the concepts of virtual mobility and \\
virtual exchange; creating open educational objects; and, developing virtual \\
mobility skills.
\end{tabular}




\begin{tabular}{|c|c|}
\hline $\begin{array}{l}\text { Task and } \\
\text { support }\end{array}$ & $\begin{array}{l}\text { Tasks students. Students are introduced for the first time to the field of Virtual } \\
\text { Mobility, although the topic for the joint work is known as they are asked to } \\
\text { co-design a short proposal for Primary Education. }\end{array}$ \\
\hline & $\begin{array}{l}\text { Tasks teacher. The design of the activity is developed by a group of teachers } \\
\text { from both contexts and their share interaction with students in the social } \\
\text { networked used for the VM activity with students. However, each national } \\
\text { team of teachers are responsible for the assessment of their students. }\end{array}$ \\
\hline & $\begin{array}{l}\text { Support for students. Students are given an introductory session and written } \\
\text { instructions for the activity. Also, they receive support by both teams of } \\
\text { teachers in the social network. Being active teachers, with this support, } \\
\text { students are expected to self-direct their performance and self-regulate their } \\
\text { learning. }\end{array}$ \\
\hline & $\begin{array}{l}\text { Support for teachers. Teachers do not have particular support for the VM } \\
\text { activity in itself. }\end{array}$ \\
\hline & Support for staff. There is no other staff involved in the VM activity in itself. \\
\hline $\begin{array}{l}\text { Roles and } \\
\text { responsibilities }\end{array}$ & $\begin{array}{l}\text { Roles student. Students develop the whole activity in international teams } \\
\text { except for the final reflective task. }\end{array}$ \\
\hline & $\begin{array}{l}\text { Roles teacher. Teachers follow students weekly as they share the same } \\
\text { network groups and can monitor the whole process of exchanges. Teachers } \\
\text { agree in one message weekly in order to guide the task during the scheduled } \\
\text { period. }\end{array}$ \\
\hline & $\begin{array}{l}\text { Responsibilities student. Students take the responsibility to meet and } \\
\text { develop the task although they are not free to group themselves. }\end{array}$ \\
\hline & $\begin{array}{l}\text { Student characteristics. The group of each University is diverse, with students } \\
\text { from local sites but also from abroad, bringing diversity to the final teams } \\
\text { made by the two sites. }\end{array}$ \\
\hline & $\begin{array}{l}\text { Teacher characteristics. The team of teachers has a rather less diversity. } \\
\text { However, students from the UIB are mainly from the educational technology } \\
\text { field whereas teachers from RomaTre are from research methods and cultural } \\
\text { heritage fields. }\end{array}$ \\
\hline $\begin{array}{l}\text { Materials and } \\
\text { spaces }\end{array}$ & $\begin{array}{l}\text { Materials. All students are given the same instructions, including the } \\
\text { description of the activity, and }\end{array}$ \\
\hline & $\begin{array}{l}\text { Technical environment. This is the best improvement since first edition and } \\
\text { an ethical social network is introduced so students share networks where to } \\
\text { meet easily. Also, regarding the videoconferences tools, this year was easy to } \\
\text { facilitate institutional platforms. }\end{array}$ \\
\hline & $\begin{array}{l}\text { Places. Students interact internationally in social networks and online } \\
\text { meetings. Students at local levels share face to face settings, although } \\
\text { students in the Balearic Islands also need to do online meetings between } \\
\text { them if they are based in different islands. }\end{array}$ \\
\hline & $\begin{array}{l}\text { Times. Students are encouraged to meet both synchronously and } \\
\text { asynchronously. }\end{array}$ \\
\hline & $\begin{array}{l}\text { Institutional embedding. The learning activity is embedded in a subject of } \\
\text { their Teacher Students programs of the RomaTre and the UIB universities. } \\
\text { Student-created artefacts. Students are asked to submit a joint Open } \\
\text { Educational Resources (OER) with the suitable licences. }\end{array}$ \\
\hline
\end{tabular}


Students were given a schedule for the VM activity, which was based on the last years' edition. The following table, based on Poce et al. (2020b) presents this current edition calendar and reports the actual events and issues arisen.

Table 2: $\quad$ Schedule of the VM activity

\begin{tabular}{|c|c|}
\hline & Recommendation \\
\hline $\begin{array}{l}\text { Week } 0 \\
\text { October }\end{array}$ & $\begin{array}{l}\text { Students are introduced to the OpenVM activity in the context of their subjects. } \\
\text { They are given the opportunity to choose the activity among many others. Less } \\
\text { students than in the course 2019-20, especially from the Spanish University, } \\
\text { choose this project. }\end{array}$ \\
\hline $\begin{array}{l}\text { Week } 1 \\
2^{\text {nd }} \text { November }\end{array}$ & $\begin{array}{l}\text { Students join the OpenVM activity groups in MEWE, the social and ethical } \\
\text { network. When they register, they find a salutation message from teachers. } \\
\text { They post their first messages for salutation too. Some students join with some } \\
\text { delay. } \\
\text { Students of both Universities agree for the meeting date and the VC platform. } \\
\text { Some groups use Doodle, and some other agree in the date by exchanging } \\
\text { messages in the social network. They prepare the meeting at local level. } \\
\text { Groups at the UIB also join students from different islands which adds greater } \\
\text { difficulties for communication as this local step also needs videoconference } \\
\text { sessions for their meetings and initial agreements. }\end{array}$ \\
\hline $\begin{array}{l}\text { Week } 2 \\
9^{\text {th }} \text { November }\end{array}$ & $\begin{array}{l}\text { Students meet using institutional videoconference platforms and take } \\
\text { decisions on their topic and learning design. } \\
\text { Lecturers at the UIB need to program the online sessions as this is only possible } \\
\text { by teachers. }\end{array}$ \\
\hline $\begin{array}{l}\text { Week } 3 \\
16^{\text {th }} \text { November }\end{array}$ & $\begin{array}{l}\text { Students work on the joint presentation. Some problems arise in particular due } \\
\text { to the low engagement of some students. }\end{array}$ \\
\hline $\begin{array}{l}\text { Week } 4 \\
23^{\text {rd }} \text { November }\end{array}$ & Students add their individual slides to the presentation with reflective texts. \\
\hline $\begin{array}{l}\text { Week } 5 \\
30^{\text {th }} \text { November }\end{array}$ & $\begin{array}{l}\text { Last editions and submission. Students answer the survey for research aims. } \\
\text { Only half of the students answer the survey. }\end{array}$ \\
\hline
\end{tabular}

\section{Research}

The current study is aimed at exploring the development of the Open Virtual Mobility activity. The following research questions guided our study:

- What is the level of satisfaction among students?

- What skills do students perceive they have developed more?

- What skills do student perceive as more relevant for Primary Education?

To answer these questions, we adopted a descriptive approach, and a mixed methodology was designed, with quantitative and qualitative techniques to explore students' perceptions. So, first of all, data was collected with a Likert-scale survey that was sent to students through the social network used for the learning activity, and each question was written in English and translated into Italian and Spanish in order to ensure correct understanding. The survey was created ad hoc to explore the learning design in general terms and included the following five elements: the learning activity, international context, 
the social network, the group of peers and the role of teachers. The question on skills development followed the framework by Rajagopal et al. (2020b). The quantitative data is then completed with a text analysis of students' final pieces of reflection and open comments to explore with greater depth their satisfaction and perception on learning skills.

\section{Results}

For the first research question, we explored both general satisfaction and also looked for more detailed information on the elements of the learning design. As can be seen in Figure 1, all students with no exceptions were satisfied or very satisfied.

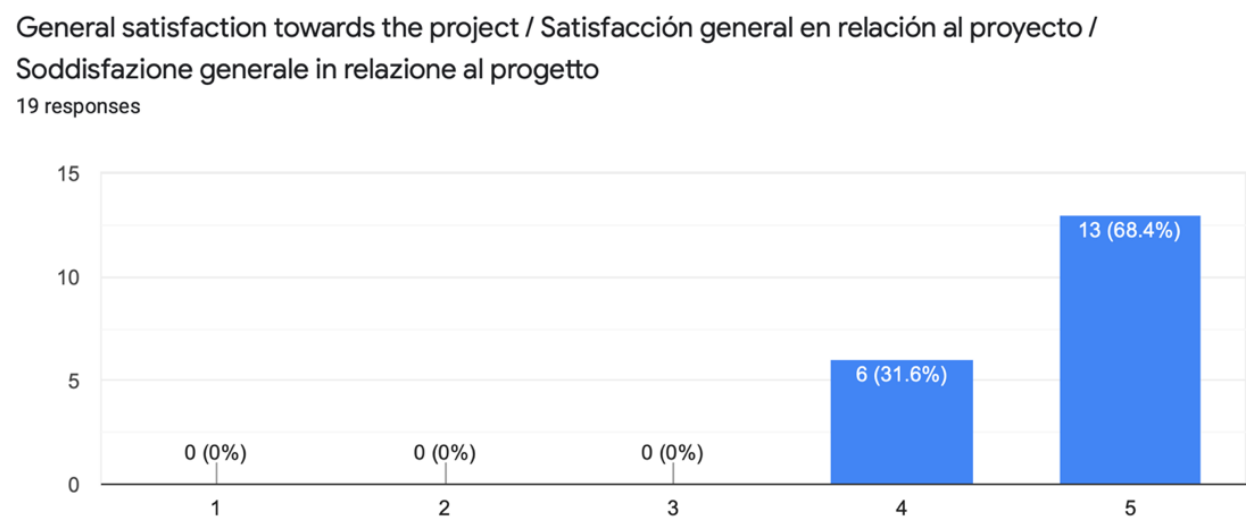

Figure 1. General satisfaction towards the project

Satisfaction was also generalized when asking about five elements of the learning experience (Figure 2), but there are some nuances that allow us to observe limitations to improve for future editions for the activity. In general, it can be seen that again all elements obtain a high level of agreement at higher scores of satisfaction, and among all, it can be highlighted that the social network and the role played by teachers are the elements with better results (11 answers at level 5 and 3 at level 4). However, all questions obtain neutral answers which in general, allow us to think that there is still room to improve the current learning design. There is no element that receives a single answer of total un-satisfaction but nonetheless, the international context of the activity, the social network and the group of peers obtain an answer at level 2, which means a rather unsatisfied student involved in the activity. 


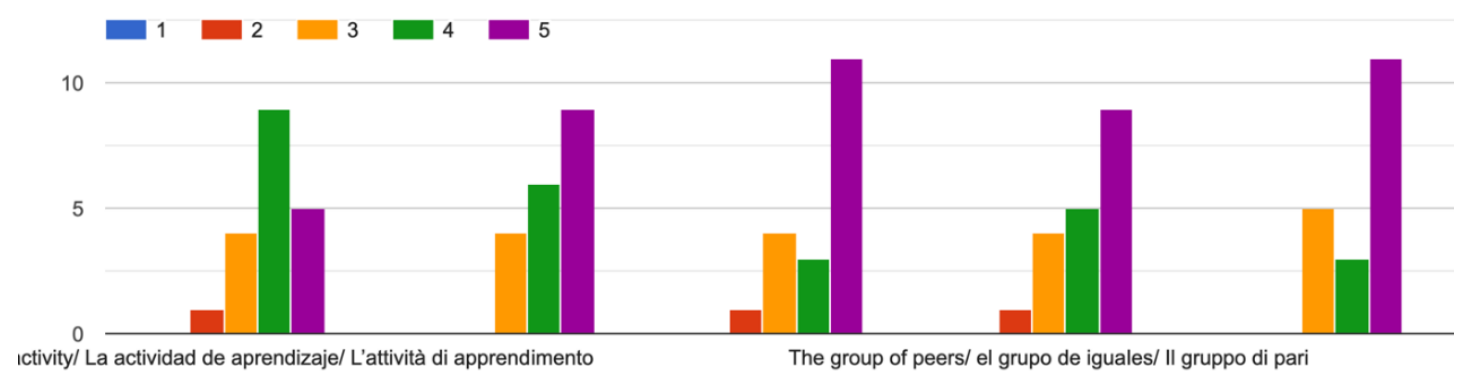

Figure 2. Level of satisfaction towards five elements of the learning design

There are some comments by students that complete the meaning of the quantitative results. In general, although they encountered language and teamwork difficulties, they are satisfied with the experience and the tools that they recommend to repeat it in future courses and they are willing to transfer the experience to their future teaching. The following texts show these ideas (translated from Italian or Spanish):

- Student 2 adds the limitations due to linguistic barriers: "It was an exciting and constructive experience. Even if at times difficult because of the different language but stimulating because of it."

- Student 6 highlights the tools that were new and praises the organization of the activity: "I learnt new tools, both MeWe (an interesting social network with no ads or followers...) Doodle (great for an organisation of this type) and the ones chosen in the group. Undoubtedly a good experience that I would repeat again on another occasion and that in the near future I would like to do with my students. (...)"

- Student 7 recommends new editions of the VM project: "The project seems very interesting and useful to me. I think it should continue so that more courses take a more elaborate form and can collect more content."

- Student 11 enjoyed the activity but points out the difficulties for honest teamwork of all members of the group: "I really enjoyed this experience but not everyone in my group participated :(. Great work from the teachers. Thank you very much."

Figure 3 shows the results for the question about their skill development due to the VM activity, and results are very positive with some nuances to be commented. Again, it is relevant to point out that all questions obtain answers of neutral perceptions, and only three skills seem not to have been developed at all by very few students: the collaborative learning and the active SRL (one student) and, networked learning (two students). All skills obtain more than half of the answers at a highest scores (levels 4 and 5 of agreement). 
Open mindedness is the skill with more answers at level 5, and adding together scores 4 and 5 , the total of agreement is of 15 students, which is the same results as intercultural skills and attitude, autonomy- driven learning, media and digital literacy, active selfregulated learning, and the knowledge of Virtual Mobility and Open Education.

Level of development of skills. Choose from 1 to 5 (1- Not at all ; 2 - Low; 3- Neutral; 4 - Moderate; 5 - High) / Nivell de dearrollo de las compentencias. Elige desde 1 a 5 ( 1 - Nada ; 2 Bajo; 3- Neutral; 4 - Moderado; 5 - Alto ) / Livello di sviluppo delle competenze. Selezionare...ne da 1a 5 (1- Per niente; 2 - Poce; 3- Neutro; 4 - Abbastanza; 5 - Alto) per ogni competenza

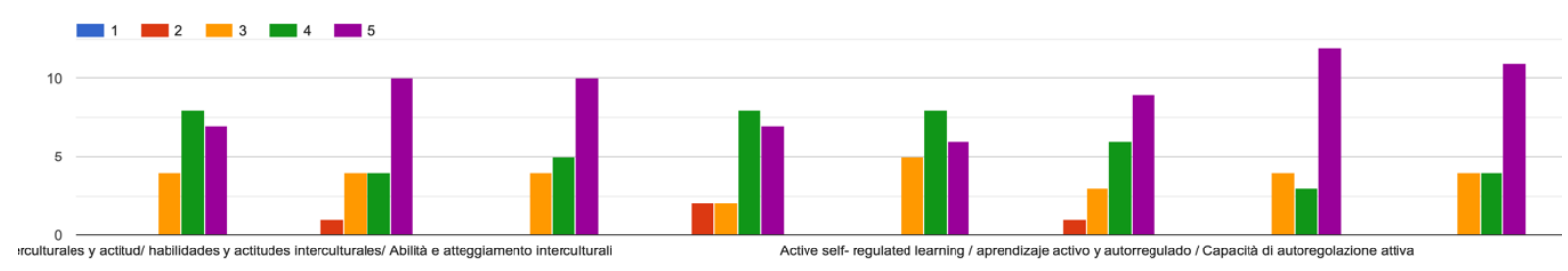

Figure 3. Students' perception for the development of skills

Comments by students highlight the development of some skills (mainly digital, openmindedness and collaborative, intercultural skills) from the Open Virtual Mobility framework:

- Student 10 focuses on the development of language, digital, open-mindedness and collaborative skills: "This virtual mobility experience was an effective opportunity to practice and enhance our skills in using online learning and research technologies. Collaborating with colleagues in the context of an international learning experience has certainly contributed to improving our language skills but, above all, it has enriched us from a human point of view, prompting us to work on our open-mindedness, on the value of tolerance, thus improving our teamwork skills."

- Student 1 observes the collaborative potential for intercultural learning and the relevance of the activity in the current pandemic times: "In my opinion, this experience was very positive and interesting. The collaboration with the group was active and participative on the part of all those involved. The different realities of which the students are bearers has allowed a greater realisation of the concept of multicultural integration and in a historical moment like the one we are in, having had the opportunity to cooperate and virtually meet new people has certainly produced multiple benefits for the realisation of the project itself, but also for individual development."

- Student 15 highlights the diversity of skills needs for success collaborative projects: "Group work involves multiple skills for success, from digital skills to interpersonal skills. This collaborative work has been very fruitful." 
As for their envisioning of the importance of these skills for Primary Education, it is surprising the level of the agreement that there is in most of the skills. Only for the collaborative skills, one student answers with disagreement whereas the vast majority of the group answers with the highest score. The networked learning is the skill with less answers at level 5 although the greatest part of student agree about the need to develop it during Primary Education (14 students' answers levels 4 and 5).

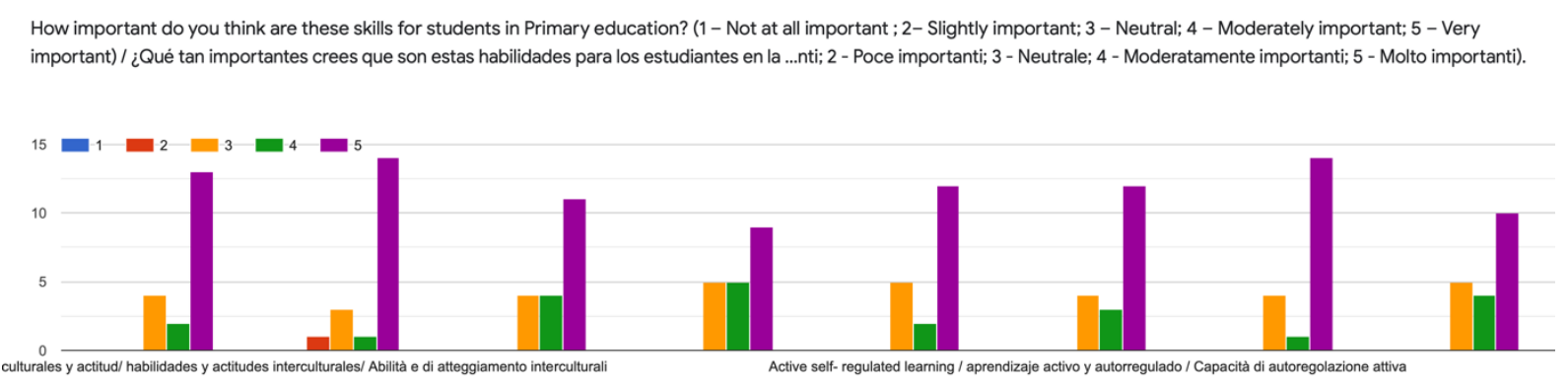

Figure 4.

\section{Discussion and conclusion}

This current learning design is a contribution towards the improvement of curriculum based on collaborative and co-designed international projects (Tur \& Buchem, 2021). As for the first research question, this second edition has been successful as students' satisfaction may suggest. However, the low number of students that take part from the Spanish university again suggest the need to further improve the VM activity, probably by ensuring understanding and promoting motivation in the subject introduction. The research about the skills seems to confirm the development at different levels of the set of skills defined by Rajagopal et al. (2020a) but extends knowledge on Primary Education. Last year's iteration of the Open VM activity between RomaTre and the UIB allowed us to observe some limitations (Poce et al. 2020b) that have been greatly solved in this current edition, in particular those related to the digital environment: sharing a Virtual Learning Environment, in which students can communicate and share with lecturers at the same time. During preparation, an ethical social network was suggested and it seems that it was a successful decision. However, it stills needs to be improved with the synchronous session of all students for the presentation of all OERs done by students to clarify the objectives and support motivation. 


\section{References}

Buchem, I., Tur, G., \& Urbina, S. (2018). Quality assurance for attainment, assessment and recognition of virtual mobility skills in context of open education. QA Framework in the Open Virtual Mobility project. EDULEARN18 Proceedings, 945-952. Edulearn Conference, 2-4 July 2018. Retrieved from https://iated.org/concrete3/view_abstract.php?paper_id=65036

International Association of Universities (2020). Regional/National Perspectives on the Impact of COVID-19 on Higher Education. Paris: International Association of Universities (IAU) UNESCO House.

Kaplan, A. (2020). Covid-19: A (potential) chance for the digitalization of higher education. ESCP Business School. Retrieved from https://academ.escpeurope.eu/pub/IP\%202020-72-EN.pdf

Op de Beeck, I., \& Van Petegem, W. (2013). Virtual mobility: an alternative or complement to physical mobility? ERACON 2011 \& 2012 Dual Year Proceedings, 151160.

Poce, A., Amenduni, F., Re, M., \& De Medio, C. (2020a). Assessing a MOOC users experience in a virtual mobility project: preliminary results for quality enhancement. Italian Journal of Educational Technology.

Poce, A., Tur, G., Amenduni, F., \& Darder, A. (2020b). Open Virtual Mobility between student teachers from Italy and Spain: an opportunity for the enhancement of the curriculum. Poster presented at "Human and Artificial Intelligence for the Society of the Future” EDEN 2020 Annual Conference, 22-24 June 2020.

Rajagopal, K., Firssova, O., Op de Beeck, I., van der Stappen, E., Stoyanov, S., Henderikx, P., \& Buchem, I. (2020a). Learner skills in open virtual mobility. Research in Learning Technology, 28. https://doi.org/10.25304/rlt.v28.2254

Rajagopal, K., Brouns, F., Firssova, O., \& Op de Beeck, I. (2020b). Open VM Design Guide. Retrieved from https://www.openvirtualmobility.eu/topics/outputs/o1framework-and-guidelines/

Ruiz Corbella, M., \& Garcia Aretio, L. (2010). Movilidad virtual en la educación superior: ¿oportunidad o utopía? Revista Española de Pedagogía, 246, 243-260. Retrieved from https://reunir.unir.net/bitstream/handle/123456789/3854/MovilidadVirtualEnLaEdu cacionSuperior.pdf?sequence $=1 \&$ isAllowed $=\mathrm{y}$

Tur, G., \& Buchem, I. (2021). Special issue editorial. Virtual mobility: opening up educational mobilities. Edutec. Revista Electrónica De Tecnología Educativa, 75, 1-8. https://doi.org/10.21556/edutec.2021.75.1987 


\section{Authors}

The present contribution was edited in the following order: Gemma Tur: sections "Results" and "Discussion and conclusion"; Antonella Poce: section "Introduction"; Maria Rosaria Re: sections "The Virtual Mobility learning design" and "Research"; Sofia Villatoro: sections Results" and "Discussion and conclusion". 